\title{
STRATEGI PENGEMBANGAN BUDAYA PEMBELAJARAN DI SEKOLAH
}

\author{
Winarto, Lantip Diat Prasojo \\ SMKN 1 Girimulyo KulonProgo Yogyakarta, FIP Universitas Negeri Yogyakarta \\ winartoakt@yahoo.co.id, lantip1975@gmail.com
}

\begin{abstract}
Abstrak
Penelitian ini bertujuan untuk memahami dan menganalisis manajemen budaya belajar yang ada di SMKN 2 Depok, Sleman dan SMKN 2 Yogyakarta. Penelitian ini merupakan penelitian studi kasus dengan pendekatan kualitatif. Data dianalisis menggunakan teknik analisis interaktif model Miles dan Huberman. Hasil penelitian ini adalah sebagai berikut. (1) Budaya belajar dibentuk dan dikembangkan berdasar pada analisis masalah yang dihadapi dan analisis kebutuhan yang ada. (2) Budaya belajar peserta didik merupakan sikap dan perilaku yang dilakukan oleh peserta didik dalam proses pendidikan dan pembelajaran. Budaya belajar terbentuk melalui proses penanaman nilai-nilai dan norma-norma dalam setiap program dan kegiatan yang telah disusun oleh sekolah. (3) Manajemen budaya belajar tidak berdiri sendiri dalam sebuah program atau kegiatan khusus, namun melekat pada setiap program dan kegiatan pada setiap bidang yang ada di sekolah. Manajemen budaya belajar mengacu pada fungsi-fungsi pokok manajemen secara umum, yang meliputi empat fungsi pokok, yakni perencanaan (planning), pengorganisasian (organizing), pelaksanaan (actuating) dan pengendalian (controlling). (4) Faktor yang mendasari pentingnya manajemen budaya belajar meliputi: perkembangan ilmu pengetahuan, teknologi dan informasi yang semakin cepat, tingkat persaingan yang semakin ketat, dan tuntutan dunia usaha dan industri.
\end{abstract}

Kata kunci: Nilai dan norma, budaya belajar, manajemen

\section{STRATEGY OF DEVELOPING LEARNING CULTURE IN SCHOOL}

\author{
Winarto, Lantip Diat Prasojo \\ SMKN 1 Girimulyo KulonProgo Yogyakarta, FIP Universitas Negeri Yogyakarta \\ winartoakt@yahoo.co.id, lantip1975@gmail.com
}

\begin{abstract}
This research aims to understand and analyze study culture management in SMKN 2 Depok, Sleman and SMKN 2 Yogyakarta. This research is a case study with the qualitative approach. The data were analyzed using the interractiveanalysis technique of Miles and Huberman model. The research results are as follows. (1) The study culture is built and developed based on the problem analysis and need analysis. (2) The study culture is students attitude and behavior on education and learning process. The study culture is built on internalization values and norms in the school's programs and activities. (3) The culture study management is not in one special program and activity, but it is included in every program and activity in school activity. The study culture management is based on the four general management functions: planning, organizing, actuating, and controlling. (4) The study culture management is necessary based on some factors, including science technology and information development, high rate of competition and industrial demand.
\end{abstract}

Keywords: values and norms, study culture, and management 


\section{Pendahuluan}

Sekolah Menengah Kejuruan (SMK) adalah salah satu lembaga pendidikan yang bertujuan menghasilkan sumber daya manusia yang cerdas, trampil, kompeten dan profesional serta memiliki akhlaq dan karakter yang kuat, sehingga siap memasuki dunia kerja sesuai dengan bidang keahlian yang dipilihnya. Untuk mencapai hal tersebut, diperlukan suatu proses pendidikan dan pembelajaran yang berkualitas. Banyak faktor yang berpengaruh terhadap kualitas pembelajaran di sekolah. Faktor tersebut diantaranya adalah: faktor kepemimpinan kepala sekolah, kondisi sarana prasarana, sumber daya manusia (tenaga pendidik dan kependidikan), input (peserta didik) dan lingkungan belajar siswa.

Salah satu aspek penentu keberhasilan proses belajar peserta didik di sekolah adalah pembentukan sikap dan perilaku peserta didik dalam belajar. Sikap dan perilaku anak dalam belajar, dibentuk dan dikembangkan melalui penanaman nilai dan norma tertentu dalam setiap program dan kegiatan pembelajaran. Pengelolaan tersebut dapat dinamakan sebagai manajemen budaya belajar. Manajemen budaya belajar tersebut bukan merupakan suatu bagian yang berdiri sendiri, namun melekat dalam setiap program dan kegiatan yang ada di sekolah. Budaya belajar yang kondusif, akan mendorong terbentuknya sikap dan perilaku anak yang efektif pula dalam proses pembelajaran. Tumbuhnya budaya belajar di sekolah sangat dipengaruhi oleh situasi dan kondisi lingkungan sekolah di mana peserta didik berada. Lingkungan yang nyaman dan kondusif akan mampu mendorong sikap dan perilaku siswa yang lebih efektif dalam belajar. Akhirnya, sekolah dapat dijadikan sebagai wahana pembentukan sikap dan perilaku peserta didik yang efektif, sebagai bekal menjalani kehidupan dan penghidupannya.

Manajemen budaya belajar menjadi sesuatu yang penting dan sangat dibutuhkan bagi setiap lembaga pendidikan, terutama untuk mencapai keberhasilan proses pendidikan dan pembelajaran. Secara umum, manajemen meliputi empat fungsi pokok, yaitu fungsi perencanaan, pengorganisasian, pelaksanaan dan fungsi pengendalian. Sedangkan budaya belajar menekankan pada sikap dan perilaku individu dalam proses pendidikan dan pembelajaran yang dilandasi atas nilai dan norma tertentu. Esensi utama dalam budaya belajar ini adalah memahami makna budaya, sebagai unsur pokok dalam manajemen budaya belajar. Untuk hal tersebut, perlu diperhatikan seperti apa yang dikemukakan oleh Taylor (Suharsaputra, 2013, p. 92) yang menyebutkan bahwa budaya (culture) adalah "the complex whole which includes knowledge, belief, art, morals, law, custom and any other capabilities and habits acquired by man as a member of society".

Budaya merupakan sesuatu yang kompleks yang meliputi ilmu pengetahuan, keyakinan, seni, moral, hukum, kebiasaan, serta kemampuan dan kebiasaan yang didapatkan oleh seseorang sebagai anggota suatu masyarakat. Dari pengertian tersebut, budaya dipandang sebagai suatu proses interaksi yang panjang di antara anggota organisasi yang ada dan lingkungannya. Budaya organisasi yang terbentuk tidak terlepas dari nilai dan norma sebagai dasar pembentukan sikap dan perilaku individu dalam organisasinya. Oleh karena itu sekolah, sebagai organisasi pembelajar memiliki peran dan fungsi yang besar dalam membentuk sikap dan perilaku peserta didik yang efektif dalam proses pembelajaran. Proses tersebut dapat dibentuk melalui manajemen budaya belajar yang diterapkan dalam lembaga tersebut.

Keberhasilan manajemen budaya belajar di sekolah tidak terlepas dari peran kepala sekolah sebagai pemimpin dan manajer lembaga tersebut. sebagai pemimpin, kepala sekolah harus mampu merumuskan visi, misi dan tujuan sekolah, yang mengandung nilai dan norma yang ingin dicapai bersama. Selanjutnya, kepala sekolah harus mampu meyakinkan kepada setiap elemen yang ada di sekolah akan arti pentingnya nilai dan norma tersebut. Selain hal tersebut, kepala sekolah juga harus mampu menciptakan suasana dan lingkungan belajar yang nyaman dan kondusif, 
sehingga dapat mendorong terbentuknya kultur sekolah yang produktif dan unik yang membedakan dengan organisasi lain.

Kultur sekolah akan terbentuk melalui proses internalisasi nilai-nilai dan norma-norma yang telah disepakati bersama dalam setiap aktivitas atau kegiatan dalam organisasi atau sekolah tersebut. Dalam posisinya sebagai manajer, kepala sekolah harus mampu merencanakan program, mengorganisir kegiatan, melaksanakan program dan kegiatan dan mampu mengendalikan program dan kegiatan yang ada, sehingga proses penanaman nilai dan norma sebagai inti dari budaya belajar di sekolah dapat berjalan secara efektif dan efisien.

Apabila diamati, permasalahan mendasar yang muncul pada sebagian besar lembaga pendidikan yang ada, khususnya di SMK adalah pada pengelolaan proses pembelajaran yang ada di sekolah. Proses pendidikan dan pembelajaran yang diberikan di sekolah belum mampu memberikan pengembangan potensi anak secara utuh. Artinya, proses pendidikan dan pembelajaran belum memberikan keseimbangan antara aspek kognitif, afektif dan aspek psikomotorik. Proses pembelajaran masih menekankan pada aspek kognitif dengan mengutamakan pada hasil belajar peserta didik dalam bentuk nilai atau angka. Pendidikan dan pembelajaran kurang mengarah pada aspek afektif, yakni pembentukan sikap dan perilaku berdasar pada nilai-nilai dan norma-norma tertentu. Dampaknya adalah kompetensi lulusan SMK masih rendah, sehingga belum banyak yang mampu bersaing dalam dunia usaha dan industri.

Nilai dan norma sebagai objek pokok dalam manajemen budaya belajar di sekolah, harus mendapatkan perhatian secara serius oleh semua elemen yang ada di sekolah. Kepala sekolah harus mampu meyakinkan akan arti pentingnya nilai dan norma tertentu, sehingga dapat diimplementasikan dengan tepat dalam setiap program dan kegiatan yang ada. Kenyataan menunjukkan bahwa sebagian besar lembaga pendidikan, khususnya SMK, pe- ngelolaan program dan kegiatan pembelajaran yang mendasarkan pada nilai dan norma tertentu kurang dikelola secara efektif. Program dan kegiatan yang ada masih bersifat rutinitas, belum ada usaha menanamkan nilai dan norma tertentu secara mendalam pada diri peserta didik. Akibatnya adalah proses pendidikan dan pembelajaran menjadi timpang, artinya anak hanya diberikan kecerdasan secara intelektual dan ketrampilan saja, tetapi kurang memperhatikan pada aspek afektif, yang mampu membentuk peserta didik yang menjadi pribadi yang jujur, penuh semangat, tanggung jawab, pantang menyerah, tidak mudah putus asa, kreatif, dan mampu menghadapi perubahan dan perkembangan yang ada.

Manajemen budaya belajar yang tidak efektif dan tidak efisien, menyebabkan peserta didik mengalami kesulitan dalam proses pembelajaran. Hal ini mengakibatkan prestasi belajar peserta didik menjadi menurun, yang pada akhirnya tingkat penguasaan kompetensi menjadi rendah. Dari data yang diambil dari Badan Pusat Statistik (BPS) Nasional tahun 2014 diperoleh informasi tentang tingkat pengangguran nasional. Informasi ini sebagai bagian data pendukung mengenai proses pendidikan dan pembelajaran yang ada di sekolah belum dilaksanakan secara optimal. Data tersebut disajikan pada Tabel 1.

Tabel 1. Tingkat Pengangguran Nasional Berdasar Pendidikan

\begin{tabular}{clrc}
\hline No & \multicolumn{1}{c}{ Tamatan } & Jumlah & $\%$ \\
\hline 1 & Tdk/blm pernah sekolah & 134.040 & 1,10 \\
2 & Blm/tdk tamat SD & 610.574 & 6,60 \\
3 & SD & 1.374 .822 & 18,18 \\
4 & SLTP & 1.693 .203 & 22,80 \\
5 & SLTA Umum & 1.893 .509 & 25,98 \\
6 & SLTA Kejuruan & 847.365 & 16,98 \\
7 & Diploma I,II,III/Akademi & 195.258 & 2,50 \\
8 & Universitas & 398.298 & 5,86 \\
\hline & Total & 7.147 .069 & 100 \\
\hline
\end{tabular}

Sumber: Badan Pusat Statistik (2014) 
Data tersebut mengindikasikan bahwa proses pendidikan dan pembelajaran di sekolah khususnya di SMK belum berjalan secara efektif dan efisien. Besarnya tingkat pengangguran, khususnya dalam jenjang pendidikan SMK tentunya disebabkan oleh banyak faktor. Dilihat dari sudut pandang budaya belajar, dapat diindikasikan bahwa peserta didik kurang memiliki nilai dan norma yang kuat dalam belajar, sehingga belum menghasilkan sikap dan perilaku yang efektif dalam proses pembelajaran. Kondisi tersebut menyebabkan budaya belajar peserta didik masih lemah. Selain hal tersebut lingkungan belajar peserta didik juga belum mampu mendorong terbentuknya sikap dan perilaku peserta didik untuk dapat tumbuh dan berkembang sesuai dengan potensinya. Sebagian besar sekolah, khususnya jenjang pendidikan SMK belum mampu menghadirkan lingkungan belajar yang kondusif dan manajemen budaya belajar yang efektif dan efisien.

Salah satu karakteristik proses pendidikan di SMK adalah menekankan pada pembentukan sikap dan perilaku, sehingga peserta didik memiliki karakter yang kuat. Sikap dan perilaku anak dalam belajar yang didasarkan pada nilai dan norma tertentu akan membentuk budaya belajar anak. Pembentukan budaya tersebut akan berjalan efektif dan efisien apabila melibatkan seluruh elemen dan unsur yang ada di sekolah. Budaya belajar yang efektif akan mampu mendorong meningkatnya prestasi peserta didik baik di bidang akademik maupun non akademik. Untuk mewujudkan hal tersebut, dunia pendidikan khususnya di lingkungan sekolah masih menghadapi banyak tantangan dan permasalahan.

Permasalahan pokok yang muncul adalah kepemimpinan kepala sekolah yang belum maksimal dalam mengelola budaya belajar di lembaga yang dipimpinnya. Proses pembelajaran kurang mendasarkan pada nilai dan norma tertentu dengan memperhatikan kondisi lingkungan dan latar belakang peserta didik. Selain hal tersebut, pendidikan karakter, sebagai bagian dari budaya belajar peserta didik di sekolah juga kurang menjadi perhatian yang serius dalam proses pendidikan dan pembelajaran. Pendidikan lebih menekankan pada pencapaian aspek kognitif dan psikomotorik dan belum menekankan pada aspek afektif atau sikap peserta didik dalam belajar. Padahal aspek afektif merupakan unsur pokok bagi kehidupan peserta didik, sehingga peserta didik mampu menghadapi dan beradaptasi dengan perkembangan dan perubahan yang terjadi.

Proses pendidikan dan pembelajaran yang kurang seimbang antara aspek kognitif, psikomotorik dan afektif akan mengakibatkan kejenuhan dalam belajar pada diri peserta didik. Anak menjadi pribadi yang terkekang, pribadi yang tidak merdeka dalam belajar, karena harus dipaksa untuk menerima sesuatu yang kurang diperlukan oleh peserta didik. Dampak yang dihasilkan adalah semangat belajar anak menjadi menurun, yang mengakibatkan prestasi belajar peserta didik juga menurun. Kondisi tersebut dapat diatasi apabila sekolah mampu mengelola budaya belajar dengan tepat, dengan didasarkan pada nilai dan norma tertentu, serta memperhatikan potensi dan sumber daya yang ada untuk mencapai tujuan dan sasaran yang telah ditetapkan.

Budaya belajar pada dasarnya merupakan nilai-nilai inti yang diyakini secara intensif oleh suatu lembaga atau organisasi, yang diterapkan dalam proses pembelajaran. Budaya belajar akan efektif apabila didukung oleh manajemen budaya belajar yang tepat. Artinya budaya belajar harus disusun bedasarkan pada perencanaan yang matang dengan mempertimbangkan semua aspek yang ada di sekolah. Selain hal tersebut, sekolah harus memiliki sistem yang kuat dan manajemen pendidikan yang kuat pula, sehingga proses penanaman nilai dan norma dalam setiap program dan kegiatan dapat berjalan secara efektif. Kenyataan menunjukkan bahwa kondisi seperti tersebut masih belum banyak dilakukan di lembaga pendidikan yang ada. Sebagian besar sekolah masih belum memiliki sistem dan manajemen pendidikan yang kuat untuk pembentukan sikap dan perilaku anak dalam belajar. 
Terdapat empat sekolah yang berkualitas dan dijadikan sebagai sekolah rujukan di Daerah Istimewa (D.I.) Yogyakarta, yaitu: SMKN 2 depok, Sleman, SMKN 2 Yogyakarta, SMKN 2 Pengasih dan SMKN 2 Wonosari. SMKN 2 Depok Sleman dan SMKN 2 Yogyakarta dijadikan sebagai tempat penelitian manajemen budaya belajar, karena kedua sekolah tersebut merupakan sekolah yang berkualitas dan menjadi sekolah rujukan di D.I. Yogyakarta. SMKN 2 Depok, Sleman memiliki masa studi 4 tahun dan SMKN 2 Yogyakarta memiliki masa studi 3 tahun dan kedua sekolah tersebut memiliki keunikan dalam pengelolaan proses pendidikan dan pembelajaran yang menghasilkan lulusan yang berkarakter. Kedua SMK tersebut diharapkan dapat mewakili dari sekolah yang berkualitas yang ada.

SMKN 2 Depok Sleman, sebagai SMK terbaik yang ada di Daerah Istimewa Yogyakarta, memiliki strategi khusus dalam mengelola budaya belajar sehingga dapat menghasilkan lulusan yang berkualitas. Sekolah berupaya memberikan pendidikan dan pembelajaran yang bermakna dengan menekankan pada aspek pembentukan sikap dan perilaku melalui proses penanaman nilai-nilai dan norma-norma yang telah diyakini dan disepakatinya sehingga mampu membentuk karakter yang kuat bagi peserta didik. Nilai-nilai dan norma-norma tersebut selanjutnya diinternalisasikan kepada seluruh warga sekolah melalui berbagai program dan kegiatan yang telah disusun oleh sekolah.

Konsep dasar pendidikan dan pembelajaran yang diselenggarakan SMKN 2 Depok Sleman adalah penekanan pada pembentukan karakter peserta didik, melalui budaya disiplin dan budaya tertib. Selain hal tersebut, kepala sekolah, tenaga pendidik dan kependidikan diupayakan untuk dapat menjadi penggerak dan teladan dalam mewujudkan budaya disiplin dan budaya tertib tersebut.

Selain SMKN 2 Depok Sleman, SMKN 2 Yogyakarta juga memiliki prestasi yang sangat baik dalam bidang akademik maupun non akademik. Lulusan lembaga tersebut memiliki daya saing yang tinggi dan banyak terserap dalam dunia usaha dan industri. Keberhasilan SMKN 2 Yogyakarta tersebut tidak terlepas dari keberhasilan kepala sekolah dalam manajemen pendidikan di lembaganya. SMKN 2 Yogyakarta juga menekankan pada aspek pembentukan sikap dan perilaku siswa dalam belajar, melalui penanaman nilai dan norma yang telah diyakininya, yang semuanya dikelola dalam bentuk manajemen budaya belajar peserta didik.

Sikap dan perilaku peserta didik dalam belajar menjadi penekanan pokok dalam manajemen budaya belajar di SMKN 2 Yogyakarta. Sikap dan perilaku dibentuk melalui proses penanaman nilai dan norma dalam diri peserta didik. Untuk mencapai kondisi tersebut, maka di SMKN 2 Yogyakarta terdapat tim budaya yang bertugas memantau dan memastikan bahwa setiap peserta didik mematahui setiap peraturan dan tata tertib yang telah dibuat oleh sekolah. Selain tim budaya, tim bimbingan konseling (BK) juga memiliki peran yang kuat dalam upaya penanaman nilai dan norma yang mendorong sikap dan perilaku anak dalam belajar menjadi lebih efektif dan efisien

Dari uraian seperti tersebut budaya belajar peserta didik memiliki peran yang besar dalam peningkatan efektivitas pendidikan dan pembelajaran. Untuk hal tersebut, penelitian ini memiliki tujuan untuk mengetahui dan mendeskripsikan budaya belajar pada SMKN 2 Depok, Sleman dan SMKN 2 Yogyakarta. Selain hal tersebut juga untuk menganalisis manajemen budaya belajar pada SMKN 2 Depok, Sleman dan SMKN 2 Yogyakarta.

Hasil penelitian ini diharapkan dapat memberikan kemanfaatan baik secara praktis maupun teoritis. Secara praktis diharapkan dapat digunakan sebagai bahan masukan dan pertimbangan bagi sekolah menengah tingkat atas, khususnya SMK, dalam manajemen budaya belajar yang terjadi di sekolah. Secara teoritis, penelitian ini diharapkan dapat memberikan kemanfaatan sebagai pembahasan dan pertimbangan untuk mengembangkan manaje- 
men budaya belajar di sekolah menengah tingkat atas, khususnya di SMK.

Pemahaman konsep budaya belajar tidak terlepas dari pemahaman makna budaya dan makna belajar. Budaya sangat dipengaruhi oleh nilai dan norma yang diyakini oleh seseorang atau sekelompok orang dalam melakukan kegiatan untuk mencapai tujuan tertentu. Sedangkan pengertian belajar dapat didefinisikan dari berbagai sudut pandang teori, yang pada intinya bahwa belajar menimbulkan berbagai perubahan pada diri seseorang.

Saifer, Edwards, Ellis, \& Ko (2011, p. 9) memberikan definisi tentang budaya sebagai berikut: a way of life, especially as it relates to the socially trasmitted habbits, customs, traditions, and beliefs that characterize a particular group of people at a particular time. It include the behavior, actions, practices, attitudes, norms, value, commucication style, language, etiquette, spirituality, concepts of health and healing, beliefs, and institution of racial, ethnic, religious, or social group.

Budaya merupakan jalan hidup terutama yang berkaitan dengan perpindahan kebiasaan, adat istiadat, tradisi dan keyakinan yang secara khusus mencirikan kelompok orang dalam kurun waktu tertentu. Hal tersebut meliputi perilaku, tindakan, praktek, sikap, norma, nilai, gaya berkomunikasi, bahasa, tatacara/etiket, spriritualitas, konsep sehat dan penyembuhan, keyakinan dan institusi rasial, etika, agama atau kelompok sosial Dari pengertian tersebut dapat dimaknai bahwa Budaya belajar mencerminkan mengenai diri seseorang dalam melakukan proses pembelajaran

Budaya belajar peserta didik tidak terlepas dari budaya organisasi di mana peserta didik belajar. Sekolah yang memiliki budaya organisasi yang kuat, yang didasarkan pada nilai dan norma tertentu akan berpengaruh terhadap budaya belajar peserta didiknya. Oleh karena itu untuk membangun budaya belajar peserta didik harus diawali dari membangun budaya organisasi (sekolah) yang bersangkutan

William Ouchi (Hoy \& Miskel, 2008, p. 177) mendefinisikan tentang budaya organisasi sebagai berikut: "organizational culture as symbols, ceremonies, and myths that commonicate the underlying values and belief of that organization to its employees". Budaya organisasi adalah simbul-simbul, upacaraupacara, mitos-mitos yang mendasari nilai dan kepercayaan pada organisasi kepada para pekerja-pekerjanya

Budaya organisasi di sekolah akan berpengaruh terhadap budaya belajar peserta didiknya. Budaya organisasi (sekolah) yang kuat, akan mendorong tumbuhnya budaya belajar yang kuat pula. Budaya belajar di sekolah, akan terbentuk jika setiap elemen yang ada di sekolah memiliki kesadaran dan komitmen yang kuat akan nilai dan norma yang menjadi dasar pembentukan budaya belajar. Selanjutnya nilai dan norma akan diinternalisasikan melalui berbagai proses kegiatan, sehingga mampu mehasilkan suatu kebiasaan pada diri individu dalam menjalani proses belajarnya.

Manajemen budaya belajar pada dasarnya merupakan bagian dari manajemen pendidikan yang ada di sekolah. Faktor utama dalam manajemen budaya belajar adalah terjadinya proses internalisasi dan asimilasi nilai, norma, kebiasaan dan keyakinan yang telah disadari dan disepakati untuk mencapai proses pembelajaran yang efektif. Keberhasilan proses internalisasi dan asimilasi nilai dan norma tersebut, tidak lepas dari pemahaman proses pendidikan dan pembelajaran yang ada di sekolah.

Proses pendidikan dan pembelajaran peserta didik harus mencakup semua ranah pendidikan, artinya pendidikan bukan hanya sekedar memberikan tambahan pengetahuan atau membangun aspek kognitif dan psikomotorik peserta didik saja, namun pendidikan juga harus memperhatikan pembentukan sikap dan perilaku peserta didik untuk memcapai hal tersebut, budaya belajar peserta didik perlu dikelalo secara tepat, melalui penerapan fungsifungsi manajemen secara tepat pula.

George R. Terry (Engkoswara \& Komariah, 2010, p. 87) juga mendefinisikan manajemen sebagai berikut "Management is a distinct process consisting of planning, organizing, actuating, and controlling, performed to determine and accomplish stated objectives by 
use human beings and other resources". Manajemen adalah suatu proses khas yang terdiri dari perencanaan, pengorganisasian, pelaksanaan, dan pengawasan yang dilakukan untuk menentukan dan menyelesaikan tujuan melalui manusia dan sumber-sumber yang lainnya

Manajemen budaya belajar pada dasarnya merupakan bagian dari manajemen pendidikan di sekolah. Manajemen budaya belajar melekat pada manajemen program dan kegiatan yang ada di sekolah. Keberhasilan manajemen budaya belajar terletak pada kemampuan kepala sekolah dalam memahami danmengimplementasikan nilainilai dan norma-norma yang ada dalam setiap program dan kegiatan yang dilakukan.

Pembentukan budaya belajar di sekolah harus didasarkan pada perencanaan yang matang. Kauffman (Engkoswara \& Komariah, 2010, p. 49) menyatakan bahwa "perencanaan adalah proses penentuan tujuan atau sasaran yang hendak dicapai dan menetapkan jalan dan sumber yang diperlukan untuk mencapai tujuan itu seefisien dan sefektif mungkin."

Setelah program dan kegiatan direncanakan secara tepat, langkah selanjutnya adalah pengorganisasian program dan kegiatan, khususnya yang berkaitan dengan budaya belajar peserta didik. Thariq Ghayyur (Wibowo, 2013, p. 55) memberikan batasan tentang pengorganisasian sebagai berikut: "it involves the process of determining what tasks are to be done. Who is to do them? How the tasks are to be grouped? Who reports to whom and where decisions are to be made". Pengorganisasian merupakan suatu proses pentuan tugas-tugas yang harus dilakukan, bagaimana tugas-tugas tersebut dikelompokkan dan siapa yang harus melapor tentang keputusan yang telah dibuat.

Tahap ketiga dari fungsi manajemen ini adalah pelaksanaan program dan kegiatan. Program dan kegiatan yang dilaksanakan adalah dalam rangkai mengimplementasikan nilai dan norma pada peserta didik melalui program dan kegiatan yang telah disusun. Pelaksanaan berkaitan erat dengan kegiatan pemimpin atau manajer dalam memberikan pengarahan sumber daya yang ada dalam organisasi. Pengarahan berarti menggerakkan sumber daya yang ada, khususnya sumber daya manusia (SDM) untuk melaksanakan pekerjaan secara bersama-sama sesuai dengan yang telah direncanakan organisasi.

Tahap terakhir dari fungsi manajemen adalah pengawasan (controlling). Pengawasan atau pengendalian merupakan kegiatan yang dilakukan pemimpin berupa pengamatan dan pengukuran kegiatan operasional apakah sudah sesuai dengan rencana yang ditetapkan atau belum. Mockler (Engkoswara \& Komariah, 2010, p. 219) memberikan definisi tentang pengawasan sebagai berikut: Suatu usaha sistematis untuk menetapkan standar pelaksanaan dengan tujuan-tujuan perencanaan, merancang sistem informasi umpan balik, membandingkan kegiatan nyata dengan standar yang telah ditetapkan sebelumnya, menentukan dan mengukur penyimpangan-penyimpangan, serta mengambil tindakan koreksi yang diperlukan untuk menjamin bahwa semua sumber daya perusahaan digunakan dengan cara paling efektif dan efisien dalam tujuan-tujuan organisasi. Tujuan dari pengawasan adalah mengendalikan kegiatan agar sesuai dengan rencana yang telah ditetapkan.

\section{Metode Penelitian}

Jenis penelitian ini adalah studi kasus dengan pendekatan kualitatif. Penelitian ini menitikberatkan pada pembentukan sikap dan perilaku peserta didik dalam belajar di SMKN 2 Depok Sleman dan SMKN 2 Yogyakarta dengan menekankan pada penanaman nilai dan norma tertentu,

Penelitian ini dilakukan di SMKN 2 Depok, Sleman dan SMKN 2 Yogyakarta. Kedua SMK tersebut dipilih sebagai tempat penelitian, karena merupakan sekolah yang memiliki keunggulan baik dalam prestasi akademik maupun non-akademik, di antara empat SMK yang berkualitas yang ada di Daerah Istimewa Yogyakarta. Penelitian dilakukan pada bulan Januari sampai dengan Mei 2015. Subjek dari penelitian ini adalah Quality Management Representative 
(QMR), wakil kepala sekolah, dan tenaga pendidik.

Penelitian dengan pendekatan kualitatif dengan jenis studi kasus ini menggunakan teknik observasi, wawancara dan dokumentasi dalam pengambilan data. Untuk meningkatkan keabsahan data peneliti menggunakan uji keabsahan data, yaitu dengan melakukan perpanjangan pengamatan di lapangan, peningkatan ketekunan dalam penelitian, dan triangulasi data. Selain hal tersebut juga dilakukan diskusi dengan teman sejawat dan membercheck.

Data yang dikumpulkan berupa program dan kegiatan, yang mengandung nilai dan norma tertentu, untuk membentuk budaya belajar siswa. Instrumen dalam penelitian ini adalah peneliti sendiri, yang langsung terjun ke lapangan untuk melakukan pengumpulan data secara lengkap dan akurat. Untuk meningkatkan kualitas data yang dikumpulkan, maka alat bantu yang digunakan dalam pengumpulan data ini adalah sebagai berukut: pedoman wawancara, lembar observasi dan alat dokumentasi kegiatan. Data dikumpulkan dengan tiga cara yakni obesrvasi, wawancara dan dokumentasi.

Data yang telah terkumpul kemudian dianalisis dengan menggunakan analisis interaktive models dari Miles \& Huberman (1984). Prosesnya, setelah data terkumpul, kemudian dilakukan reduksi data. Reduksi data merupakan suatu proses untuk menyederhanakan data yang dikumpulkan, dengan cara memilih dan memilah sesuai dengan kebutuhan, sehingga data yang ada mudah dipahami, terutama yang berkaitan dengan permasalahan budaya belajar peserta didik di SMKN 2 Depok, Sleman dan SMKN 2 Yogyakarta.

Tahap selanjutnya adalah data display atau penyajian data. Dalam tahap ini peneliti menyajikan atau menampilkan data yang telah dikumpulkan dan dianalisis sebelumnya. Data yang disajikan adalah data yang telah diolah, data yang telah disesuaikan dengan tema pokok penelitian yang diambil, yakni masalah manajemen budaya belajar. Penyajian data dalam penelitian ini adalah dengan teks yang bersifat naratif.
Tahap terakhir adalah conclusion atau penarikan kesimpulan. Tahap ini merupakan kegiatan yang mendeskripsikan dan menganalisis tentang bagaimana budaya belajar di SMKN 2 Depok, Sleman dan SMKN 2 Yogyakarta dan bagaimana pengelolaanya. Kesimpulan didasarkan pada data yang diperoleh melalui observasi, data dokumen dan wawancara seperti yang telah dilakukan pada tahap-tahap sebelumnya. Proses penarikan kesimpulan didasarkan pada fokus atau tema penelitian yang ada, sehingga memberikan kejelasan terhadap permasalahan yang sedang diteliti

\section{Hasil Penelitian dan Pembahasan}

\section{Deskripsi Budaya Belajar di SMKN 2 Depok Sleman}

Budaya belajar peserta didik di SMKN 2 Depok Sleman menggambarkan tentang bagaimana sikap dan perilaku peserta didik dalam belajar dan juga bagaimana mereka berinteraksi dengan lingkunganya selama proses pembelajaran. Sikap dan perilaku tersebut didasari oleh nilai-nilai dan norma-norma yang tertanam dalam diri peserta didik. Sikap dan perilaku tersebut terbentuk melalui proses penanaman nilai dan norma yang telah diyakini dan disepakati oleh lembaga, dalam upaya mencapai tujuan dan sasaran yang telah ditetapkan.

Keberhasilan proses pendidikan dan pembelajaran di SMKN 2 Depok Sleman dibangun melalui berbagai tahapan. Salah satunya adalah dengan pembentukan sikap dan perilaku peserta didik dalam belajar, melalui proses penanaman nilai dan norma yang positif dan produktif. Semenjak peserta didik masuk di SMKN 2 Depok Sleman, para peserta didik sudah dikenalkan dengan nilai dan norma yang harus dijalankan. Nilai dan norma tersebut diarahkan untuk membentuk sikap dan perilaku anak dalam belajar.

Manajemen budaya belajar di SMKN 2 Depok Sleman ditekankan pada aspek pembentukan sikap dan perilaku peserta didik dalam mengikuti proses pendidikan dan pembelajaran di sekolah. Sikap dan perilaku peserta didik dipengaruhi oleh se- 
berapa kuat nilai dan norma dapat ditanamkan pada diri peserta didik. Untuk mencapai hal tersebut, fungsi-fungsi manajemen diterapkan secara tepat untuk mencapai budaya belajar yang efektif dan efisien. Fungsi-fungsi tersebut adalah fungsi perencanaan, pengorganisasian, pelaksanaan dan pengawasan.

Rencana program pengembangan budaya belajar disusun oleh kepala sekolah dibantu oleh para wakil kepala sekolah. Seluruh program diarahkan untuk membentuk sikap dan perilaku peserta didik, sehingga proses pembelajaran dapat terlaksana dengan efektif. Rencana program pengembangan budaya belajar melibatkan semua bidang yang ada di sekolah.

Pengorganisasian dilakukan untuk mengoptimalkan sumber daya yang ada. Kepala sekolah sebagai top management memiliki tugas dan tanggung jawab memberdayakan sumber daya yang ada, sehingga program yang telah disusun dan direncanakan dapat berjalan secara efektif dan efisien. Untuk mencapai hal tersebut telah disusun struktur organisasi yang jelas dan tegas, yang menggambarkan aliran tugas dan tanggung jawab dari setiap bidang yang ada.

Pelaksanaan program pengembangan budaya belajar dilaksanakan secara terpadu oleh semua bidang yang ada di SMKN 2 Depok Sleman. di bidang kurikulum terdapat program bedah SKL, les mata pelajaran dan try out bagi siswa kelas 3 . Tryout dilaksanakan setiap minggu sekali pada hari Sabtu, yang bertujuan untuk memantau perkembangan prestasi peserta didik. Selain hal tersebut juga ada kegiatan Achievement Motivation Training (AMT), outdoor learning, prakerin (selama 6 bulan) dan magang di dunia usaha dan industri.

Pelaksanaan program di bidang kesiswaan yakni adanya budaya disiplin dan budaya tertib yang sangat ketat, hal ini terbukti adanya skor yang jelas bagi yang melanggar tata tertib. Selain hal tersebut juga ada program open house, tryout dan jaring aspirasi. Program open house merupakan program sosialisasi sekolah kepada calon siswa dengan tujuan memberikan gambaran secara lengkap mengenai proses pendidikan dan pembelajaran di SMKN 2 Depok Sleman. Program ini diharapkan dapat memberikan kejelasan bagi calon siswa baru, sehingga dapat mempersiapkan dan menyesuaikan dengan kegiatan yang ada di sekolah.

Program jaring aspirasi merupakan program untuk menyerap aspirasi warga sekolah, khususnya peserta didik terhadap semua pelayanan pendidikan dan pembelajaran yang telah dilakukan oleh sekolah. Kegiatan ini dimaksudkan untuk menyerap seluruh masukan, keluhan dari semua warga sekolah, sehingga dapat dijadikan sebagai dasar dalam penyusunan program kerja sekolah. Sedangkan program tryout merupakan salah satu kegiatan untuk memetakan kemampuan calon peserta didik baru yang akan masuk dalam program keahlian tertentu.

Di bidang hubungan masyarakat dan hubungan industri (humas hubin) dilakukan pengembangan budaya belajar melalui perbaikan dan peningkatan nilai sikap para peserta didik, melalui analisis outcome, atau analisis softskill peserta didik. Analisis softskill lulusan ini ditujukan untuk menemukan apa yang menjadi kelemahan dan kekurangan sekolah dalam membina dan mengembangkan sikap peserta didik selama proses pembelajaran.

Pengendalian program merupakan usaha untuk menjamin pelaksanaan program dan kegiatan sesuai dengan yang telah direncanakan. Untuk meningkatkan efektivitas pengendalian atau pengawasan program budaya belajar setiap bidang yang ada saling berkoordinasi. Program pengembangan dan pembentukan budaya belajar di SMKN 2 Depok Sleman dikendalikan oleh setiap bidang yang ada. Setiap bidang melakukan evaluasi terhadap program dan kegiatan yang telah dilaksanakan. Dari hasil evaluasi tersebut dijadikan sebagai dasar dan bahan masukan bagi manajemen untuk menyusun program lebih lanjut.

Manajemen budaya belajar di SMKN 2 Depok Sleman merupakan suatu hal yang sangat diperlukan. Manajemen budaya belajar akan menghasilkan sikap dan 
perilaku yang positif dan produktif dalam belajar. terdapat banyak faktor yang melatarbelakangi mengapa manajemen budaya belajar tersebut penting. Salah satu faktornya adalah perkembangan ilmu pengetahuan, teknologi dan informasi yang semakin pesat.

Faktor lain adalah tingkat persaingan yang semakin ketat, dan tuntutan dunia usaha dan industri (DU/DI) yang membutuhkan tenaga kerja yang kompeten dan berkarakter. Hal tersebut memerlukan suatu persiapan yang tepat dengan membentuk sikap dan perilaku peserta didik melalui penanaman nilai dan norma tertentu. Dunia usaha dan indistri bukan hanya membutuhkan tenaga kerja yang menguasai pengetahuan dan ketrampilan saja, namun juga membutuhkan tenaga kerja yang memiliki sikap dan perilaku yang positif dan produktif serta karakter yang kuat.

Deskripsi Budaya Belajar di SMKN 2 Yogyakarta

Budaya belajar di SMKN 2 Yogyakarta sangat dipengaruhi oleh budaya organisasi yang ada pada lembaga tersebut. SMKN 2 Yogyakarta telah menerapkan sistem manajemen mutu (SMM) ISO 9001: 2008. Atas dasar kondisi tersebut, maka setiap aktivitas yang ada pada sekolah tersebut dikendalikan secara ketat oleh bidangbidang yang ada.

Budaya belajar peserta didik dibangun dan dikembangkan dengan menekankan aspek kedisiplinan dan ketertiban. Artinya dalam proses pembelajaran terdapat serangkaian asumsi, nilai dan norma yang harus dipatuhi dalam proses pembelajaran. Kleiman (Norton, 2008, p. 235) mendefinisikan budaya sebagai berikut: " $a$ society's set of assumtions, values and rules about social interactions". Budaya merupakan serangkaian asumsi, nilai dan aturan tentang interaksi sosial. Atas hal tersebut maka, setiap peserta didik dituntut untuk taat dan patuh pada aturan dan tata tertib yang berlaku.

Untuk meningkatkan efektivitas pelaksanaan program tersebut, sekolah membentuk tim budaya yang bekerja sama dengan bimbingan konseling (BK) dalam menegakkan ketertiban dan kedisiplinan di sekolah tersebut. tim budaya memiliki tugas khusus, yakni memantau dan memastikan bahwa setiap peraturan dan tata tertib yang ada sudah dipatuhi oleh peserta didik. Selain hal tersebut tim budaya juga melakukan pendataan terhadap siswa yang melanggar peraturan dan hasilnya diserahkan pada BK. Sedangkan BK sendiri bertugas memberikan pembinaan yang bersifat mendidik, sehingga anak memiliki sikap dan perilaku yang positif dalam kegiatan pendidikan dan pembelajarannya.

Program pengembangan dan pembentukan budaya belajar di SMKN 2 Yogyakarta dikelola melalui manajemen budaya belajar yang melekat dalam setiap program dan kegiatan yang ada di sekolah. George R. Terry (Engkoswara \& Komariah, 2010, p. 87) mendefinisikan manajemen sebagai berikut "Management is a distinct process consisting of planning, organizing, actuating, and controlling, performed to determine and accomplish stated objectives by use human beings and other resources". Manajemen adalah suatu proses khas yang terdiri dari perencanaan, pengorganisasian, pelaksanaan, dan pengawasan yang dilakukan untuk menentukan dan menyelesaikan tujuan melalui manusia dan sumber-sumber yang lainnya.

Rencana program kegiatan di SMKN 2 Yogyakarta disusun secara terpadu yang melibatkan kepala sekolah beserta staff yang ada. Rencana program pengembangan budaya belajar merupakan rencana membentuk sikap dan perilaku siswa dalam belajar melalui berbagai program kegiatan yang ada di sekolah. Oleh karena itu, program pembentukan dan pengembangan budaya belajar tidak berdiri sendiri dalam satu kegiatan tertentu, tetapi melekat dalam setiap program dan kegiatan yang ada di sekolah.

Untuk meningkatkan efektivitas pelaksanaan program yang telah disusun, dilakukan pengorganisasian. Pengorganisasian merupakan kegiatan untuk membagi tugas, peran dan tanggung jawab sesuai dengan kemampuannya, sehingga tujuan 
dan sasaran yang telah direncakan dapat tercapai secara efektif dan efisien.

Kepala sekolah SMKN 2 Yogyakarta melakukan koordinasi kegitatan terutama terhadap program dan kegiatan pembentukan dan pengembangan budaya belajar bersama dengan staff yang ada. Semua tugas, wewenang dan tanggung jawab dibagi habis kepada seluruh staffnya. Koordinasi program dilakukan pada awal semester, untuk memastikan seluruh program dan kegiatan dapat terlaksana dengan efektif dan efisien.

Pelaksanaan program budaya belajar dilaksanakan melalui berbagai program unggulan. Program tersebut yaitu program pengembangan karakter berupa program $3 S$ (sapa, salam, dan senyum), doa bersama, menyanyikan lagu indonesia raya dan kajian kitab suci.

Pelaksanaan budaya belajar di SMKN 2 Yogyakarta didukung melalui program unggulan yang telah dirumuskan oleh tim pengembang sekolah. Program tersebut adalah program peningkatan lifeskill, yang meliputi lima kegiatan pokok yaitu: ekstra job, perencanaan rumah tinggal sehat, ramah lingkungan dan tahan gempa, project work pembuatan teknologi tepat guna, pelayanan service instalasi listrik dengan real job dan kegiatan Unit Produksi dan Jasa (UPJ) yang layak jual.

Program ekstra job merupakan program jurusan Teknik Kendaraan Ringan (TKR). Program ini dilakukan dengan tujuan setiap peserta didik kompeten dalam hal: manajemen service, manajemen klaim dan garansi service, manajemen wirausaha dan manajemen belanja sparepart. Untuk mendukung terlaksananya program tersebut para peserta didik dibimbing dan diawasi oleh instruktur yang profesional.

Program perencanaan rumah tinggal sehat, ramah lingkungan dan tahan gempa merupakan program unggulan program keahlian Teknik Gambar Bangunan. Program ini bertujuan untuk membina peserta didik sehingga kompeten dalam hal: membuat rancangan bangunan dari proposal sampai dengan rancang bangunan. Program yang digunakan adalah Autocad. Selain hal tersebut program ini ditujukan untuk meningkatkan daya saing peserta didik dalam dunia usaha dan industri.

Project Work teknologi tepat guna merupakan program unggulan untuk program keahlian Teknik Instalasi Tenaga Listrik (TITL). Program ini ditujukan untuk meningkatkan kompetensi siswa dalam hal pemanfaatan teknologi tepat guna dalam hal instalasi tenaga listrik. Implementasi program ini diawali dengan sebuah proposal sampai barang tersebut jadi.

Selain project work teknologi tepat guna, program keahlian TITL juga memiliki program service alat rumah tangga yang berhubungan dengan listrik. Program ini ditujukan untuk meningkatkan kompetensi siswa dalam hal pemanfaatan teknologi tepat guna dengan model real job. Sasaran program adalah seluruh perlatan yang berkaiatan dengan tenaga listrik

Fungsi manajemen yang terakhir dalam manajemen budaya belajar adalah pengendalian. Pengendalian merupakan suatu tindakan yang dilakukan oleh pemimpin atau manajer untuk mengamati dan mengukur kegiatan operasional apakah sudah sesuai dengan yang direncanakan atau belum.

\section{Simpulan}

Budaya belajar baik di SMKN 2 Depok, Sleman maupun di SMKN 2 Yogyakarta dibentuk dan dikembangkan berdasar pada analisis masalah yang dihadapi dan analisis kebutuhan yang ada. Selain hal tersebut, juga didasarkan pada analisis kebutuhan dunia usaha dan industri. Dunia usaha dan industri bukan hanya menghendaki lulusan yang cerdas dan trampil, namun juga memiliki sikap dan perilaku yang siap untuk dilatih, disesuaikan perkembangan yang ada. Terdapat tiga faktor utama dari kedua lembaga tersebut yang dijadikan sebagai dasar pembentukan budaya belajar, yaitu: perkembangan ilmu pengetahuan, teknologi dan informasi yang semakin cepat, tingkat persaingan yang semakin ketat dan tuntutan dunia usaha dan industri.

Budaya belajar di SMKN 2 Depok Sleman dan SMKN 2 Yogyakarta, terben- 
tuk melalui proses penanaman nilai-nilai dan norma-norma tertentu dalam setiap program dan kegiatan yang telah disusun oleh sekolah. Kedua lembaga tersebut memiliki kesamaan budaya belajar, yakni menekankan pada budaya disiplin dan budaya tertib dalam setiap aktivitas kegiatan yang dilakukan. Yang membedakan adalah strategi dan proses internalisasi nilai-nilai dan norma-norma dalam setiap jenis program dan kegiatan yang dilakukan oleh sekolah. Nilai dan norma yang telah diyakini dan disepakati oleh lembaga akan dijadikan sebagai dasar dalam pembentukan sikap dan perilaku anak, khususnya dalam belajar

Manajemen budaya belajar mengacu pada fungsi-fungsi pokok manajemen secara umum, yang meliputi empat fungsi pokok, yakni perencanaan (planning), pengorganisasian (organizing), pelaksanaan (actuating) dan pengendalian (controlling). Manajemen budaya belajar di SMKN 2 Depok Sleman dan SMKN 2 Yogyakarta, dibentuk dan dikembangkan melalui proses perencanaan program dan kegiatan yang didasarkan pada analisis yang tepat dengan mempertimbangkan sumber daya dan potensi yang ada. Untuk mendukung efektivitas pelaksanaan program, setiap bagian yang ada di sekolah, selalu melakukan koordinasi kegiatan sehingga setiap sumber daya yang ada mampu dioptimalkan untuk mencapai tujuan dan sasaran yang telah ditetapkan. Program dan kegiatan yang telah disusun dilaksanakan secara tepat, dengan mendasarkan pada nilai dan norma yang telah diyakini dan disepakati. Untuk memastikan bahwa program dilaksanakan sesuai dengan rencana, maka evaluasi atau pengendalian program selalu dilaksanakan.

Manajemen budaya belajar peserta didik menjadi suatu hal yang sangat penting dan perlu untuk diterapkan di SMKN 2 Depok, Sleman dan SMKN 2 Yogyakarta, karena mampu meningkatkan efektivitas proses pendidikan dan pembelajaran peserta didik. Pendidikan dan pembelajaran yang efektif akan mampu mendorong semangat belajar peserta didik meningkat, sehingga potensi yang ada pada diri peserta didik dapat berkembang secara optimal. Budaya belajar yang efektif juga akan mampu meningkatkan prestasi belajar peserta didik baik di bidang akademik maupun non akademik. Selain hal tersebut, budaya belajar yang efektif akan mampu membentuk sikap dan perilaku siswa menjadi pribadi yang berkarakter, yang mampu menghadapi dan beradaptasi dengan perkembangan dan perubahan jaman

\section{Saran}

Pembentukan budaya belajar peserta didik di sekolah, tidak terlepas dari perkembangan ilmu pengetahuan, teknologi dan informasi. Oleh karena itu kepala sekolah perlu meningkatkan kepekaan terhadap setiap perubahan yang terjadi, sehingga strategi yang diambil dapat sesuai dengan sasaran dan tujuan yang telah ditetapkan

Karakter peserta didik merupakan bagian yang pokok dalam upaya pembentukan dan pengembangan budaya belajar peserta didik di sekolah, Oleh karena itu peran dan fungsi guru sebagai tenaga pendidik harus mampu membentuk karakter yang kuat bagi peserta didiknya, melalui proses pendidikan dan pembelajaran yang membentuk kebiasaan sikap dan perilaku yang mengandung nilai dan norma tertentu. Selain hal tersebut guru juga harus mampu memberikan teladan yang baik bagi para peserta didiknya.

Budaya belajar di sekolah tidak terlepas dari lingkungan keluarga dan lingkungan masyarakat. Liningkungan keluarga dan masyarakat memiliki pengaruh yang kuat dalam upaya membentuk budaya belajar peserta didik. Oleh karena itu pihak sekolah harus membina komunikasi dan kerjasama yang aktif dengan orang tua siswa dan stakeholder terkait.

\section{Daftar Pustaka}

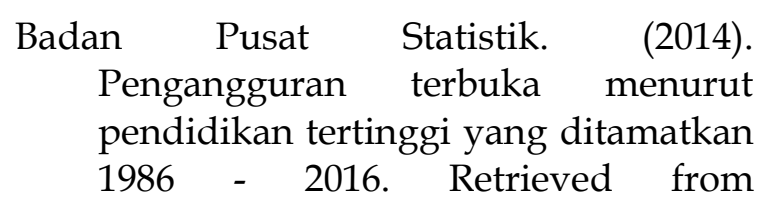


https://bps.go.id/linkTabelStatis/vie $\mathrm{w} / \mathrm{id} / 972$

Engkoswara, \& Komariah, A. (2010). Administrasi pendidikan. Bandung: CV Alfabeta.

Hoy, W. K., \& Miskel, C. G. (2008). Educational administration: Theory, research, and practice (8th ed.). New York: McGraw Hill.

Miles, M. B., \& Huberman, A. M. (1984). Qualitative data analysis: A sourcebook of new methods. Thousand Oaks, CA: Sage.

Norton, M. S. (2008). Human resources administration for educational leaders. California: Sage. Retrieved from https://uk.sagepub.com/en- $\mathrm{gb} / \mathrm{asi} /$ human-resourcesadministration-for-educationalleaders/book231824

Saifer, S., Edwards, K., Ellis, D., \& Ko, L. (2011). Culturally Responsive Standards-Based Teaching: Classroom to Community and Back. Thousand Oaks, California. https://doi.org/10.4135/97814522196 39

Suharsaputra, U. (2013). Administrasi pendidikan. Bandung: PT. Refika Aditama.

Wibowo, A. (2013). Manajemen pendidikan karakter di sekolah (konsep dan praktik implementasi). Yogyakarta: Pustaka Pelajar. 